\title{
An Appraisal of President Muhammadu Buhari's Strategic Silence on Selected National Issues and Its Implication on His Government's Image
}

DOI: https://doi.org/10.47175/rissj.v2i3.272

\section{| Andrew Asan Ate ${ }^{1}$ | Obinna Johnkennedy Chukwu² | | Jamila Abubakar Dauda ${ }^{3}$ |}

\author{
${ }^{1}$ Associate Professor/ Head, \\ Department of Mass \\ Communication, Edo State \\ University, Uzairue \\ 2,3 Department of Mass \\ Communication, Edo State \\ University, Uzairue, Edo State \\ ${ }^{1}$ dr.ate4life@gmail.com \\ 2obinnakennedy@yahoo.com \\ ${ }^{3}$ sayhi2jamila@yahoo.com
}

\begin{abstract}
This study examines the strategic silence under President Muhammadu Buhari's administration in Nigeria. Anchored on Shannon and Weaver mathematical model of communication and spiral of silence theory, the study beams a searchlight on instances of President Buhari's strategic silence, public perception of Buhari's silence on sensitive national issues; and the implications of his silence on his administration's image. The study which adopted qualitative research approach recommends that President Muhammadu Buhari should personally cultivate the culture of addressing Nigerians on sensitive national issues to give the people a sense of belonging and trust and that the president should change the negative perception of his administration by reducing the rate at which he depends on media team and spokespersons to communicate to the people on virtually everything.

KEYWORDS

Appraisal; strategic silence; national issues; government image and Buhari
\end{abstract}

\section{INTRODUCTION}

It is generally believed that silence is golden. However, in some situations, silence, can be counter-productive, especially in a political environment where people expect their leaders to address them and assuage their fears on certain issues. In politics, illicit silence is sometimes employed as a propaganda technique in communication, especially when the communicator feels that talking may bring more harm, than good to him/her. Wilson (2005, p.43) contends that a "political leader who refuse to speak on urgent public issues relinquishes to the public and the adversary press the right to read or speak his mind for him." He added that "sometimes, the mass media may overblow the issue involved in the public expectation in order to force a political leader into taking action for which he may be strongly criticized if he fails to achieve the expected results." (Wilson 2005, p.43).

In this era of citizen journalism, a leader's silence over an important issue can be dissected from diverse perspectives from the court of public opinion. Since the coming on board of President Muhammadu Buhari as president and Commander- in -Chief of the armed forces in Nigeria, he has displayed strategic silence at certain times on sensitive national issues. The development makes a lot of people wonder the kind of image the silence will confer on his government. Buhari's spokespersons often interpret his silence to his personality and "style." This discourse examines President Muhammadu Buhari's strategic silence on selected national issues viz-a-viz its implication on his government's image. 


\section{Objectives of the study}

This study is set to address the following objectives:

1. To identify instances of president Muhammadu Buhari's strategic silence in communication

2. To evaluate the publics' perception of president Buhari's silence on sensitive national issues

3. To examine the implication of president Buhari's silence on his administration's image

\section{LITERATURE REVIEW}

The key concepts to be handled here are strategic silence and government's image.

\section{Strategic Silence}

The Longman Dictionary of Contemporary English (2000, p. 1336) defines silence as complete, absence of noise. Webster Universal Dictionary and Thesaurus (2010, p437) sees silence as the absence of sound; this time thus lasts, refusal to speak or make a sound; secrecy.

Wilson (2005, p.43) defines strategic silence as the deliberate use of silence to communicate certain feelings like anger, distancing, rejection, etc, in order to achieve a set of personal objectives. He noted that strategic silence is "the perception of certain public events and refusing to speak on them so as to achieve for self or group." Strategic silence also known as strategic inaction. Oxford Review Encyclopedia of Terms sees silence as the conscious and purposeful process whereby organisations fail to publicize or mention material fact.

This can either be negative material ranging from support of a political party to holding an accident or spillage, or a positive material like gaining a certification or endorsement. Baran (2019) outlines five reasons for strategic silence in dealership:

1. Negative people and situations speak for themselves

2. The newscaster reporting these events isn't fixing them

3. Being silence is better than speaking emotionally

4. They break the silence, you win and

5. Electronic silence in still silence

According to Maor (n.d), strategic silence takes place when an organization takes a calculated decision to avoid internal and external communication in order to advance some long term goals. When a reputational threat emerges, the likelihood that the organization will be faced with negative media coverage and be drawn into public criticisms increase. Strategic silence is then employed to minimize the potential association of the organization with the reputational threat (p.823) There is a growing body of literature on silence in communication by scholars. Wilson (2005) x-rayed President Shehu Aliyu Shagari's use of strategic political silence and that of General Sani Abacha.

Under the administration of Shagari, who ruled Nigeria from October 1979, Wilson (2005, p.49) outlines areas of display of strategic political silence as follows:

- Criticisms of the president 's economic policies and alleged mismanagement of the nation's economy made by the leader of the unity party of Nigeria (UPN), Chief Obafemi Awolowo

- The Nigerian Labour congress (NLC) strike of 1982;

- The Dr. Paul Unongo's affairs;

- The invasion of Nigeria's territory by Cameroonian gendarmems;

- The deportation of Alhaji Shugaba; 
- The Bakori Dam massacre

- Godwin Daboh's allegations of impropriety against Dr. Chuba Okadigbo, the political adviser to president Shagari;

- The Maitatstine-inspired religious riot and

- Press criticisms by political party newspapers and other media in states not controlled by the National Party of Nigeria (NPN).

Under the regime of General Sani Abacha who took over power from 1993 to 1998, the following cases bothering on strategic political silence are documented by Wilson (2005, p.54):

- The fuel crises and strikes of 1994, 1997, and 1998;

- $\quad$ ASUU strike of 1994, 1995/96, 1997 and 1998;

- Abacha's arrest and detention of Bashorun M.K.O. Abiola in 1994;

- NUPENG/PENGASSAN leaders arrest and detention;

- Arrest, detention, trial and conviction of General Oladipo Diya, Abacha's second in command in another alleged coup plot (1997);

- Clamour for the improvement of workers' welfare;

- Campaign by Abacha boys for his self-succession (1997-1998) and

- The arrest, trial and execution of the Ogoni 9.

Wilson (2005, p.57) captures the differences between Shagari's use of strategic silence and that of General Abacha:

There were clear differences between president Shagari's use of strategic silence and that of Abacha's. Shagari was conscious of the civilian democratic system he was supposed to be running. Some of the situations that confronted him were not as volatile as those that Abacha faced. Shagari won an election and felt that it could only be through another election that he could be legitimately removed. Abacha was a usurper, a pretender and a blood testy vengeance seeking dictator who was afraid of his shadows. Shagari was of the people, Buhari was of the Military and hence, he was too pre-emptory.

Wilson (2005, p.57) opines that "in a country where almost all issues are politicalized, it may not be a misdirected charge to say that in some of the cases, the leaders' saw public criticisms through the media as ethnic propaganda."

\section{Image}

This is known as the perceptions and beliefs of the people regarding organization, individuals, products, services, and so on (Keghku, 2005, p.176). Corporate image refers to "the totality of all impressions formed about an organization based on the influences impacted upon by corporate identity (Nweke, 2001, p.212). Corporate image has a communication undercurrent. According to Nweke (2001, p.213) it is ' the conglomeration of people's attitudes, opinions, beliefs, that organizations established through several factorial influences and built overtime, consequent upon organizational action utterances and general relationship with its publics."

Good governance is predicated on the ability of leaders to "provide answers to societal needs and expectations through open communication and good performance" (Nweke 2001, p.244).

Communication can be a risky venture, the same thing applies to silence. Carson (2008, p.224) contends that "some issues confronting us seem so big, so overwhelming that we become paralyzed and unable to respond at all. More often than not, our lack of response is 
the manifestation often even bigger societal threat the risk of complacency." Longfellow cited in Oloyode (2008, p.1) observe that "there are three silences. This first of speech, the second of desire and the third of thought." It is important to stress here that all silence has the ability and capacity to positively affect the image of a person, organization or government.

\section{Empirical Review}

Udeze, Ekwe and Chukwuma (2013) in a paper titled "the use of strategic silence in interpersonal communication" probed the extent to which strategic silence is used in communication, interrogated whether strategic silence is used intentionally by individuals in inter-personal communication and evaluated the influence of strategic silence has in communication (p.37).

The study adopted the explanatory mixed methods design in probing the phenomenon. Anchored on interpersonal deception theory (IDT), findings from the study revealed that strategic silence is used in interpersonal communication to a minimal extent and that strategic silence is intentionally employed in interpersonal communication.

Findings also indicate that strategic silence plays both positive and negative roles in interpersonal communication. The study also affirmed that strategic silence has much in that strategic silence has much influence in interpersonal communication.

In the study titled "when silence is golden? The use of strategic silence in crisis communication".

Le, Tew, Li \& Goh (2019) investigates the following: under what circumstances do organization keep silence in crisis? How does organization's silence intensify the crisis? What leads the organization to break the silence? How is organization's image affected after silence is broken?

The study employed case studies research approach in investigating the phenomenon. Findings revealed that silence was intentionally adopted by each organization/ leader for different motives. Data in terms of effects, show silence as a retrospective intensifier; silence as an intensifier in the information vacuum; silence producing polarizing perceptions and silence having minimal/ no intensification. Findings also indicate that in the case of avoiding or hiding silence," various situational factors prompted the organization to issue a response against its will.

\section{Theoretical Framework}

This study is anchored on Shannon and Weaver mathematical model of 1949, and spiral of silence theory.

\section{Shannon and Weaver Mathematical Model}

Narula (2010, p.48) contends that the model "follows a left to right process. The speaker select a desired message from all the possible messages. The message is sent through transmitter (a communication channel), and it changed into signals. The signals are received by the receiver" she added that in the process of message transmission, "certain distortions are added to the signal which are not part of the message send by the source and we call this NOISE (Narula 2010, p.48). Shannon and Weaver model holds that silence does not communicate (Penna and Mocei, 2015) against other views that silence communicate (Anolli, 2002). 


\section{Spiral of Silence Theory}

The theory which was propounded by Elizabeth Noelle-Neumann, holds that opinion climate perception affects political opinion expression. The concept refers to increasing pressure people feel to conceal their views when they think they are in minority. (Griffin 2010, p.372). McQuail (1994, p.361) outlines the main assumption of the theory as propounded by Noelle- Neumann:

1. Society threatens deviant individuals with isolation

2. Individuals experience fear of isolation continuously

3. The fear of isolation causes individual to try to assess the climate of opinion at all times

The results of this estimate affect their behavior in public, especially, their willingness to express opinions openly. Noelle-Neuman according to Griffin (2010, p.376) pontificates that individuals who notice that their own opinion is spreading and is taken over everything, will voice their self- confidently in public, on the other hand, individuals who notice that their own opinion are losing grounds will be inclined to adopt a more reserved attitude.

The major driver of this theory is the fear of isolation which is described as "the centrifugal force that accelerates the spiral of silence" Griffin (2010, p.373).

Sambe (2008, p.191) argues that this theory" rests on the assumption that one's opinion is to a very large extent dependent upon what other people think or rather upon what others think, or rather upon what one perceives as the opinion of others,"

Since this theory is celebrated with dominant paradigms or gaining opinion in public discourse, the role of the mass media cannot be under estimated. Sambe (2008, p.191) avers that "the media often defines what is the dominant view of the day. They may therefore through the definition of what is dominant, communicate expression about future trends."

This theory is apt in this study because the media can galvanize the muting of majority opinions or inferior voices in the spiral of silence.

\section{RESEARCH METHODS}

This study adopts documentation and survey research helps in investigating the phenomenon. Through documentation, expert views were gotten from newspapers, books and journals. Documented records provides a key source of data on events or groups too small and scattered or otherwise difficult to trace for national surveys to be a realistic possibility (Osemwota, 1996). For the survey design, selected experts were interviewed on the subject matter to harvest their opinions. Survey helps in collecting quick data with reasonable cost (Daramola \& Daramola, 2011).

\section{RESULTS AND DISCUSSION}

\section{Instances of President Muhammadu Buhari's Strategic Silence}

Many commentators, public affairs analysts and scholars - Aworinde; (2020) Fashua, (2020), Ezeani (2020) Akinboye (2020) and Odin-Kalu (2020) have identified different instances of President Muhammadu Buhari's strategic silence on national issues. Some of the issues are:

- Scores of Boko Haram attacks;

- Herders/farmers crises in Nigeria;

- High rate of banditry and kidnapping incidents;

- Addressing the citizenry personally on covid-19 pandemic; 
- End SARS protest; and

- 2020 protracted Academic Staff Union of Universities ( ASUU) strike.

Aworinde (2020) specifically, frowns at Buhari's silence amid scores of Boko Haram attacks, herdsmen/farmers crises, banditry incidents, kidnappings and his numerous medical vacations. On the issue of Covid -19 , the senate has to beg president Buhari to address people personally on the matter which he has been speaking through his political appointees. Akinboye (2020) opines that president Buhari should personally speak to the people on the covid-19 issue as other presidents are doing. He argues that, Donald Trump has been doing that; enlightening the United States citizens and residents on the state of things as far as Covid-19 was concerned. (The Punch, 2020)

Odin-kalu who also criticizes Buhari's strategy of speaking through political appointees always argues that "communication has a DNA. It is easy to know this is not from @ Muhammadu Buhari. It is not his syntax or sentence DNA it is not difficult to figure out who wrote this." (The punch, 2020). Contrastingly, Onouaha (2020) observes that it must not be the president alone speaking on the issues of Covid-19. According to him, "his officers are speaking enough, the health minister has been addressing the press and informing the citizens. The international airports have been closed down. The victims are been treated. I think his officers are really on top of it" (The Punch, 2020).

On end SARS Protest, the Guardian (2020) notes that "Buhari addressed the nation after violence broke out in different parts of the country and more than a week after he reacted to the end SARS protest" (Guardian, 2020). The paper also accused president Buhari of downplaying the incident as he conspicuously avoided to mention the episode in the speech after the havoc was already done. On the Academic Staff Union of Universities' (ASUU) strike, the president on December 18, 2020 broke his long silence on the nine months old strike during the $3^{\text {rd }}$ Convocation ceremony of Alex Ekwueme Federal University, Ndute-Alike Ikwo (AE-FUNAI) Ebonyi.

\section{Public Perception of President Buhari's Silence on Sensitive National Issues}

I am not surprised because for quite some time now, even before the Corona virus, I noticed that he (Buhari) does not appear so much in the public and that has made people to question if there is something go wrong... my feeling is that his health is affecting his ability to meet the expectations of the people. (Professor Onyebuchi Ezeanyi, professor of political science, University of Nigeria, Nsukka).

The truth is that, leadership now is made up of 90 percent communication, so 95 of the works of a leader these days is communication. He has to communicate in any manner; written, spoken, and even body language (Tope Fashua, 2019 Presidential candidate of Abundant Nigerian Renewal Party). We don't have leaders' per-se, we have rulers and there are differences between rulers and leaders. A leader will know the steps to take and how to address the nation. For not addressing the nation it shows the man is not in charge of governance unless we are deceiving ourselves. (Dr. Idowu Johnson, Department of political science, university of Ibadan).

"Leadership requires prompts response when there is need to take such responsibility. The silence of the president shows lack of leadership." (Chijoke Ekechukwu, a former Director- General of the Abuja Chamber of Commerce and Industry).

During the recently held \#ENDSARS protest in Nigeria, I could remember it got to a time that people were becoming impatient with president Buhari's long, uncomfortable silence in the face of lingering protest. Thank God, he eventually delivered a recorded speech which did not go down well with some Nigerians. (Rev. Father,Anaweokhai Valentine 2020, p.7). 
Raising Philosophical questions, Anaweokhai (2021, p.7) poses:

At what stage during the protest was the president supposed to address Nigerians? Could his timely address have averted the ugly twist in the well organized and peaceful protests by Nigerian youths that unfortunately turned bloody in the indelible Lekki toll gate, desecration of the sacredness of human lives and blatant abuse of the right to peaceful protest? Why was the address not live? There are bureaucratic process in government. My assessment of Buhari is that he always allow bureaucratic process to take its course and after getting full information on committee especially on issues of security, it is at this point that he comes up and respond. Some other presidents act immediately after anything happens. Dr. Mrs. Harriet Efanador- Obeten, Head. Department of Political Science and Public Administration, Edo State University Uzairue.

The president's silence on key national issues is not pleasing to a lot of Nigerians and also to myself. There may be reasons to think that he may want to take his time in taking decisions so that he will not take the wrong decision, but one expect that given the impact of the crisis on the economy, he should be able to come out with a fast decision to remedy the situation (Dr. Mrs Evelyn Ogbeide, Director, Entrepreneurial studies, Edo State University Uzairue)

Let me start with the saying that there lies the head that wears the cap, the president has not actually been quiet concerning these issues. There are a lot of protocols that need to be followed regarding national issues which the president himself has to follow.

In most cases, things may be happening but the president has not been officially briefed and as such cannot take action until he gets official reports. I believe that is what has been happening in the president's case.

Dr. Mrs. Antonia Otsupius, Lecturer, Department of Business Administration, Edo University Uzairue).

First of all President Buhari is not silent on any national issue because he reacts as the events unfolds. In each national issue, the president has responded adequately. I do not agree that he is silent in the case of Boko Haram, the president took action by going to the United States to discuss the possibility of fighter jets for the country. For ENDSARS issue, he has set up committee to look into it and give report to him. It is based on the report that he will take action (Dr. Nathaniel Umukoro, Lecturer, Department of Political Science and Public Administration, Edo state university Uzairue).

For me, the silent strategy is working for him, he has chosen the strategy because whatever he says will be used against him. The president does not talk much, it is his media aids who speak for him, as a communicator, it does not go well with me because not saying something is saying something in another way (Dr. Wilfred Olley, Lecturer, Department of Mass Communication, Edo State University Uzairue.

The president's silence on sensitive national issues gives the impression that he is in support of what is happening or he is part of it. We cannot tell but for the fact that he is silent when he is supposed to take action or say something is unacceptable because his words can go a long way Dr. Solomon Anwuzie, head of English Department, Edo University Uzairue).

As a government, there are agencies and bodies to handle certain issues, these bodies are set up by the government to take of certain issues as they arrive. The president has delegated these bodies for respective activities. I don't think it is necessary for the president to talk on every given issue (Prof. Dawood Egbefo, Dean, Faculty of Arts, Management and Social Sciences, Edo State University Uzairue).

I looked at the president's silence on key national issues as inefficiency. A good leader should personally address his citizens on issues from time to time. Personally, I feel he is 
deliberately trying to abandon Nigerians to their fate, this could be inefficiency, negligence or the desire to remain neutral which is not the best. (Prof. Godwin Vaaseh, Head, Department of history and International Studies, Edo State University Uzairue.)

\section{Implications of President Buhari's Silence on his Administration's Image}

Like I said earlier, I don't think the president is silent on national issues, He is just a little bit slow to take action which has made a lot of things go wrong as things that could have been tackled head-on are prolonged (Dr. Mrs. Harriet Efanador-Obeten. Head, Department of Political Studies and Public Administration. Edo State University Uzairue)

Intentional silence becomes more injurious and harmful than shortest of speech, to say the least. Silence to this extent becomes immoral when intentional silence becomes an indirect way of promoting systematic and standard evil, sufferings of all forms of discrimination, injustice and oppression then it is even preferable to speak. We may have to be compelled to accept the bitter truth and reality that the time has come for the unity of Nigeria to be negotiated (Rev. Fr. Anaweokhai 2021, p.7)

Citizens are not happy the way president Buhari responds to issues of national interest, his silence is giving a negative image to his administration (Dr. Mrs. Evelyn Ogbeide. Director Entrepreneurial studies, Edo State University Uzairue).

The president's silence makes people to make their interpretations differently...he should say something, because his not saying anything is portraying his administration in a bad light (Dr. Mrs. Antonia Otsupius, Lecturer, Department of Business Administration, Edo State University Uzairue).

The president is not silent as he takes every issue with corresponding action (Dr. Nathaniel Umukoro, Lecturer, Department of Political Science and Public Administration, Edo State University Uzairue).

The president's silence has affected his administration adversely, it is making people to loss interest in his administration and it is making people to believe that there is a cabal telling him when to respond and when not to, thereby making people believe that the president is not in charge; the president's silence is a problem in his administration, anytime he leaves the gap in communication, the citizens will fill it and give it a wrong narrative (Dr. Wilfred Olley, Lecturer, Department of Mass Communication, Edo State University Uzairue).

His silence has done too many damages to the country, it has made his government to fail the people; his silence has made some governors to take actions which shouldn't be taken and it has led to loss of lives and properties. (Dr. Solomon Awuzie, Head Department of History and International Studies, Edo State University Uzairue).

As I said earlier, the president has not really been silent because he takes action on every issue that comes up, he may not talk directly to Nigerians but he takes action through appropriate bodies. This does not mean that he is inefficient but takes his actions bureaucratically (Prof. Dawood Egbefo, Dean Faculty of Arts Management and Social Sciences, Edo State University Uzairue).

His silence on important national issues is making things worst at the moment, there is lawlessness in the country. His silence is making people believe that he is in support of what is happening, in support of particular group against another, his silence depicts that there is conspiracy somewhere (Prof. Godwin Vaaseh, Head Department of History and International Studies, Edo State Uzairue). 


\section{Data Analysis}

Data revealed instances of president Buhari's Strategic silence on national issues which includes security issues like Boko Haram Attacks, Farmer/Herder crisis, banditry and kidnapping ENDSARS protest, lack of personal address on people on COVID 19 pandemic among others. It is in public domain that president Buhari did not tackle these issues head-on in proactive communication to the public. Anaweokhai (2021, p.7) questions the justification of Buhari's silence on national issues;

What kind of silence is considered golden when the unity of a people is becoming more endangered and obviously calling for renegotiations. When the assurances of our nationhood and sovereignty is an inch away from annihilation and subjugation, when peace, justice and security are fast fading like mist from our horizon, the abyss of the Armageddon, never to return? When lies, deceit falsehood and cheap propaganda have over-ridden the sanctity of truth, honesty and integrity. When the aroma of mutual suspicion and distrust pervade the entire landscape of collective humanity and those elected to offer words of hope, assurance and encouragement to the people when it matters most, are silent and mute like cadavers in the graveyard. It is at moments like these that silence is no longer golden.

Wilson (2005, p.43) argues that anytime the public does not get expected feed back to their numerous non-verbal signals which they have sent through other communication channels (especially through the mass media) in other to elicit the desired information from him, their expectations grow and the leader's silence becomes deafening..

On the public perception of President Muhammadu Buhari's silence on key national issues, data indicates that eight out of 12 people perceive that president Buhari was silent on key national issues. Those that belonged to the school of thought alluded that Mr. President's ill health is affecting his ability to meet the people's expectations in terms of communication, that he speaks more often through his media aids instead of directly addressing Nigerians. These group of people view Buhari's silence as sign of inefficiency since modern governance is about communication.

Data however, show that four out of 12 people reasoned that President Muhammadu Buhari is not silent on national issues but communicating following bureaucratic processes in government, they believe that president Buhari react to events as they unfold adequately following protocols and laid down procedures. They alluded that president Buhari is eloquently speaking through appropriate agencies and bodies.

The spiral of silence theory comes into play in this discourse. Noelle-Neuman cited by Griffin (2010, p.376) alludes that "individuals who notice that their own opinion is spreading and is taken over everything, will voice their opinion self-confidently in public." Conversely Noelle- Newman argues that "individuals who notice that their own opinion are losing round will be inclined to adopt more referred attitude'" (Griffin 2010, p.376). Based on the above theory, it could also be interpreted that president Buhari's silence on sensitive national issues may be due the losing grounds or fading relevance of his opinions. The implications of these development is clearly articulated by Wilson (2005, p.43) thus;

...the political leader who refuses to speak on urgent national issues relinquishes

to the public and the adversary press the right to read or speak his mind for him.

Sometimes, the media may over-blow the issue involved in the public

expectation order to force a political leader taking an action for which he may

also be strongly criticized if he failed to achieve the expected results.

Data on implication of Buhari's silence on his administrations image sees the silence as immoral and indirect endorsement of impunity. That Buhari's silence gives a negative 
image of his government and portrays his administration in a bad light. According to data, the president's silence is making Nigerians to believe that there is a cabal dictating to him when to speak. Another implication of Buhari's silence on his administration's image, judging from the data, is that it has done a lot of damage to the country and has led to the destruction of lives and properties. Other assertions on the issues at stake is that Buhari's silence breeds lawlessness in the country and depicts a conspiracy narrative. In another development, respondents who denied that President Buhari has not been silent noted that he is only a little bit slow. Believers in this school of thought argues that President Buhari takes on every issue with corresponding action and that he speaks frequently to Nigerians through appropriate bodies and agencies.

Scott (1972) cited by Wilson (2005, p.44) notes that silence is a cultivated attribute to leaders who assume distance in order to enhance their political power. Majority of the respondents alluded that Buhari has been silent on sensitive national issues. It can be , based on Scott's position, that Buhari's strategic silence on issues may be politically interpreted even through his style and personality cannot also be wished away.

Shannon and Weaver's model assumes that silence does not communicate. In a political environment especially in a democratic society, communication is constantly needed to effectively govern the people without suspicion or prejudices.

\section{CONCLUSION}

This study concludes that president Muhammad Buhari's administration has some instances of strategic silence by failing to proactively respond to certain sensitive national issues. Again, the study confirms that majority of the respondents perceive that president Buhari has been silent on sensitive national issues that needs his personal attention and communication. Buhari's silence on key national issues has negatively dented the image of his administration in diverse ways.

\section{Suggestions and Recommendations}

Based on the findings of the study, it is recommended as follows:

- President Muhammadu Buhari should personally cultivate the culture of addressing Nigerians on sensitive national issues to give the people a sense of belonging and trust.

- President Muhammadu Buhari should redeem his administration's battered image by frequently communication with different segments of Nigerians using the mainstream media, social media and below- the- line communication approaches.

- President Muhammadu Buhari should change the negative perception of his administration by reducing the rate at which he depends on media team and spokespersons to communicate to the people on virtually everything. He should develop a strategy of speaking to the people directly and timely to put to rest issues that may nosedive into crisis if not properly handled.

\section{REFERENCES}

Anaweokhai, V. (2021). When silence is no longer golden the promise February 2021, p.7 vol 16:2

Anoli, L. (2002). Discommunicatzione communicazione patoligical in Anolli (ed) psicologica della communicazione, Balogna il-Mulino, pp 273-304

Beran, D. (2019). Strategic silence in leadership. Accessed through medium.com

Carson, B. (2008). Take the risk Michigan: Zondavan. 
Daramola, I \& Daramola, B. (2011). Research method in social sciences and management Lagos: Rothan Press Ltd

Griffin, E. (2010). A first look at communication theory Newyork: McGraw Hill

Keghku, T. (2005). Public relations and the Nigerian Economy. Makurdu; Aboki publishers

Longman Dictionary of contemporary English (Third Edition) 2000 England: Longman

Maor, M. (e.d) strategic silence in the sage encyclopaedia of corporate reputation. Accessed through sk.sagepub.com

Nweke, O.F.(2001). Public relations practice, concepts and strategies. Enugu: Hamson-pal.

Narula, U (2010). Mass communication. Theory and practice. New Delhi: Har-Anand publication PVT ltd

Osemwota, O. (1996). Data collection techniques in Osemwota O. Okhakhu, M.A \& Tonwe, D.A (eds) research and statistical methods in social sciences, humanities and education. Lagos; Amfitos book company

Phuog D. Le, Hui Xun Teo, Augustine Peng, Yuling Li and Cai-qin Goh. (2019). When silence is golden; the use of strategic silence in crisis management. Corporate communication; an international journal 24 (1) accessed http://ink.lirary.smu.edu.sg

LE, P.D; TED, H.X; LI, Y.S \& GOH (2019)B

Udeze, E. Sunny, Ekwe, Okwudiri \& Chukwuma (2013). The use of strategic silence in interpersonal communication new media and mass communication. Vol 17 www.iltste.org

Webster's universal dictionary \& thesaurus. (2010). Glasgow; Geddes \& Grosset

Wilson, D. (2005). New perspectives in applied communication Ibadan; Stirling-Horden (Nig) Ltd the oxford review encyclopedia of terms (ed) www.oxfordreview.com

Penna, M. P \& Mocei, S. (2015). The systematic approach to communication silence e'me congeries Europeande science des systemes 